\title{
Supplementary Figure S6.
}

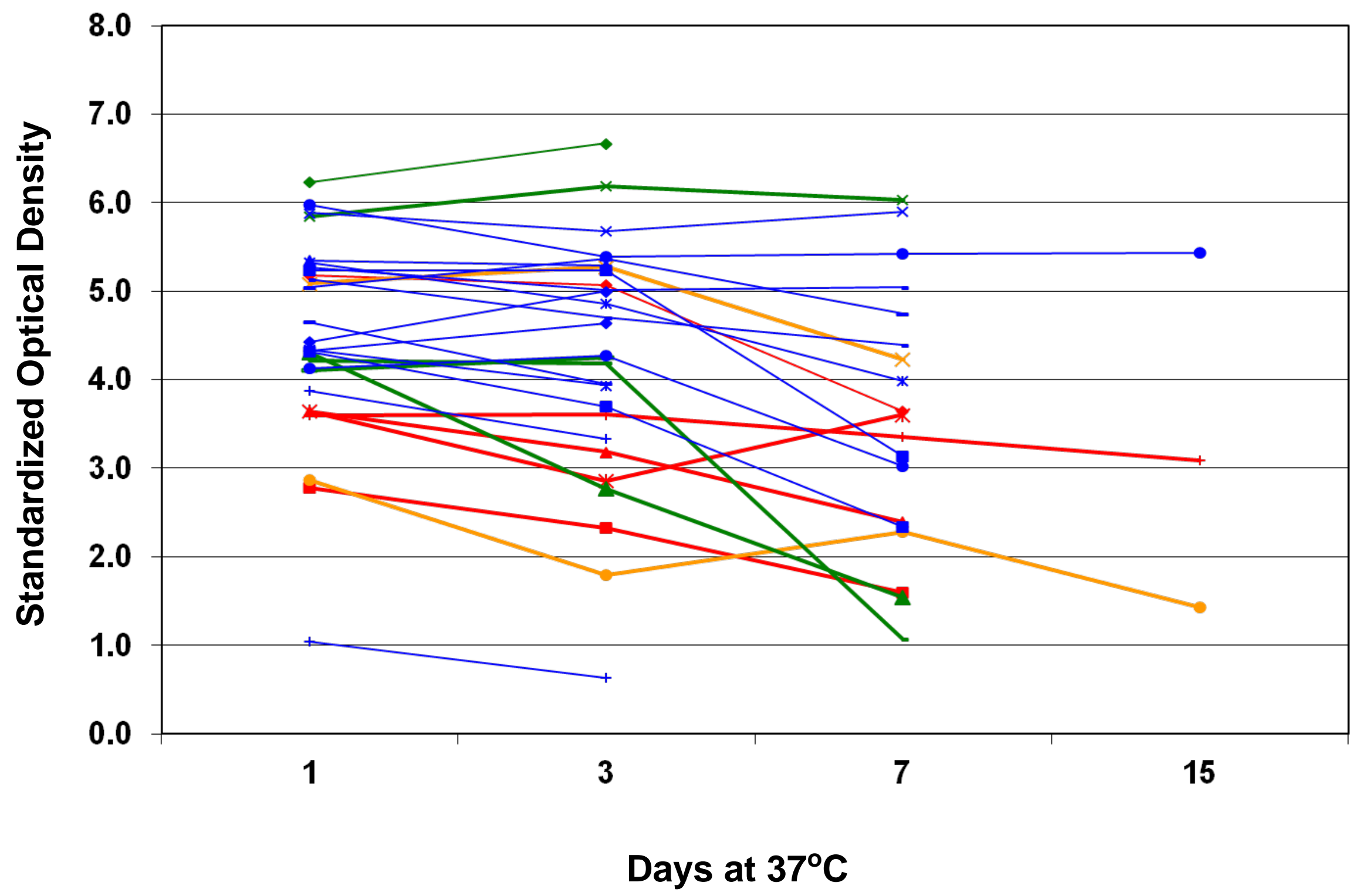

